\title{
Analisis Pengaruh Temperature Terhadap Density Crude Oil Kilang PPSDM MIGAS Dengan Pendekatan Metode Theil Pada Analisis Regresi Linier Non-Parametrik
}

\author{
Candra Irawan ${ }^{1}$, M. Hasan Syukur ${ }^{2}$ \\ ${ }^{1}$ Universitas Diponegoro, Semarang \\ ${ }^{2}$ PPSDM MIGAS, Blora
}

\section{INFORMASI NASKAH}

Diterima: 24 Februari 2021

Direvisi: 21 Mei 2021

Disetujui: 15 Nopember 2021

Terbit: 15 November 2021

Email korespondensi: mohammad.syukur@esdm.go.id Laman daring:

https://doi.org/10.37525/sp/2021$2 / 278$

\begin{abstract}
ABSTRAK
Densitas merupakan salah satu faktor yang memengaruhi kualitas dari minyak mentah. Pada proses pengukuran density of crude oil juga dilakukan pengukuran temperature crude oil tersebut. Oleh karena itu diperlukan suatu analisis guna mengetahui pengaruh temperature pada rentang $30-35^{\circ} \mathrm{C}$ terhadap density crude oil. Dalam penelitian ini, penulis akan membahas dan menganalisis mengenai pengaruh temperature terhadap density crude oil pada unit kilang dan utilitas dengan menggunakan pendekatan metode Theil pada analisis regresi linier nonparametrik. Dari hasil penelitian diperoleh model regresi liner sederhana non parametrik dengan metode Theil pada data pengaruh temperature terhadap density crude oil PPSDM Migas Cepu bulan Desember 2020 adalah: $\widehat{Y}_{\imath}=833,139-0,257 X_{i}$, dengan $\hat{Y}_{\imath}$ adalah nilai dugaan variable dependen $Y_{i}$ (density crude oil) dan $X_{i}$ adalah variable independen (temperature crude oil). Hasil pengujian menunjukkan bahwa pada taraf nyata 0,05 temperature berpengaruh terhadap density crude oil. Korelasi antara temperature dengan density crude oil memiliki korelasi yang sangat kuat dengan nilai korelasi Kendall-Tau sebesar -0,810 dan hubungan kedua variable tersebut bersifat berlawanan arah, yang dapat diartikan bahwa semakin meningkat temperature maka density crude oil akan menurun. Selang kepercayaan 0,95 koefisien slope berada pada selang $-2,298<\beta_{1}<0,007$, artinya dengan keyakinan 95\% disimpulkan bahwa density crude oil akan berkurang hingga 2,298 atau bertambah hingga $0,007 \mathrm{~kg} / \mathrm{m}^{3}$ untuk setiap pertambahan $1{ }^{\circ} \mathrm{C}$ temperature.
\end{abstract}

Kata Kunci : Density, Temperature, Crude Oil 


\section{Abstract}

Density is one of the factors that affect the quality of crude oil. In the process of measuring the density of crude oil, the temperature of the crude oil is also measured. Therefore an analysis is needed to determine the effect of temperature at range $30-35^{\circ} \mathrm{C}$ on density crude oil. In this study, the authors will discuss and analyze the effect of temperature on the density of crude oil at refinery and utility units using the Theil method approach in non-parametric linear regression analysis. From the research results obtained a non-parametric simple linear regression model with the Theil method on the effect of temperature data on density of crude oil PPSDM Migas Cepu in December 2020 is: $\widehat{Y}_{\imath}=833,139-0,257 X_{i}$,, where $\widehat{Y}_{i}$ is the estimated value of the dependent variable $Y_{i}$ (density crude oil) and $X_{\text {iare }}$ independent variables (temperature crude oil). The test results show that at a significant level of 0.05 , temperature affects the density of crude oil. The correlation between temperature and density crude oil has a very strong correlation with the Kendall-Tau correlation value of -0.810 and the relationship between the two variables is opposite, which means that the higher the temperature, the lower the density of crude oil. The confidence interval of 0.95 slope coefficient is in the range of $-2,298<\beta_{1}<0,007$, meaning that with $95 \%$ confidence it is concluded that the density crude oil will decrease to 2.298 or increase to $0.007 \mathrm{~kg} / \mathrm{m} 3$ for every $1^{\circ} \mathrm{C}$ increase in temperature.

Key word : Density, Temperature, Crude Oil

\section{PENDAHULUAN}

Minyak bumi jika diolah akan menghasilkan berbagai macam produk dengan nilai daya jual tinggi. Di Indonesia sendiri terdapat beberapa lokasi pengolahan minyak bumi, salah satunya adalah Unit Kilang di Pusat Pengembangan Sumber Daya Manusia Minyak dan Gas Bumi (PPSDM Migas) yang bekerja di bawah Kementerian Energi dan Sumber Daya Mineral. Unit kilang di PPSDM Migas memiliki kapasitas produksi sebesar 330$350 \mathrm{~m}^{3} /$ hari.

Densitas merupakan salah satu faktor yang memengaruhi kualitas dari minyak mentah. Densitas juga menjadi indikator kualitas yang penting untuk bahan bakar otomotif, penerbangan, dan perkapalan yang dapat memengaruhi penyimpanan, penanganan, dan proses pembakaran.

Pada proses pengukuran density crude oil juga dilakukan pengukuran temperature crude oil tersebut. Oleh karena itu diperlukan suatu analisis guna mengetahui pengaruh temperature terhadap density crude oil. Ukuran density crude oil yang tepat akan memudahkan proses pengolahan crude oil menjadi produk olahan berikutnya seperti solar, pertasol, kerosin, dan lain-lain.

\section{TINJAUAN PUSTAKA}

Sumber bahan baku (yakni campuran minyak mentah) kilang PPSDM MIGAS berasal dari lapangan Kawengan dan Ledok yang diambil dari sumur milik PT. Pertamina EP Asset 4 Field Cepu. Minyak bumi yang diambil dari lapangan Kawengan dan lapangan Ledok merupakan minyak HPPO (High Pour Point Oil) yang bersifat paraffinic, yaitu mengandung lilin, alkana rantai lurus dan nilai oktan rendah. Setiap pengiriman minyak mentah, laboratorium produksi pada unit kilang akan melakukan uji densitas, pour point, dan uji distilasi ASTM D-1298, untuk mengetahui 
sifat volatilitas serta spesifikasi dari minyak mentah (Khoiri, 2018).

\section{A. Density}

Uji densitas adalah uji yang sangat penting dalam penentuan kualitas suatu bahan bakar, utamanya dalam penentuan adanya kontaminasi di dalam suatu bahan bakar. Prinsip dasar dalam menentukan density dari suatu zat cair adalah dengan menggunakan Hukum Archimedes, yaitu dimana suatu benda yang memiliki volume tetap $\mathrm{V}$ dicelupkan kedalam liquida cair, maka benda yang dicelupkan tersebut akan mengalami Gaya Angkat sebesar berat zat cair yang dipindahkan. Gaya Angkat ini merupakan gaya perlawanan yang diberikan oleh zat cair terhadap benda yang dicelupkan. Akibat adanya gaya angkat tersebut, maka benda yang dicelupkan kedalam zat cair akan mengalami 3 kemungkinan, yaitu mengapung, melayang atau tenggelam.

Pada Laboratorium PHP, uji densitas dilakukan mengikuti standard ASTM D-1298. Pengujian dengan metode ASTM D-1298 dilakukan dengan urutan pengujian mencelupkan thermometer sampai didapatkan suhu yang konstan dan kemudian suhu sample dicatat dengan pembulatan sampai $0,1{ }^{\circ} \mathrm{C}$ terdekat, selanjutnya termometer dikeluarkan dari sample. Langkah selanjutnya dimasukkan hydrometer sampai melayang bebas disample uji, kemudian di catat skala density sample dengan pembulatan sampai dengan $1 / 5$ atau $1 / 10$ dari total pembagian skala di hydrometer tersebut, kemudian hydrometer dikeluarkan. Selanjutnya termometer dimasukkan kembali ke sample sampai didapatkan suhu konstan, kemudian dicatat suhu sample dengan pembulatan sampai $0,1{ }^{\circ} \mathrm{C}$ terdekat. Bilamana terdapat perbedaan hasil pengukuran suhu sample lebih dari $0,05{ }^{\circ} \mathrm{C}$ maka pengujian diulang.

Metode uji densitas ASTM D-1298 mencakup penentuan Densitas, API Gravity relative glass, atau API Gravity, dan Relatife Density (RD) dari crude oil, produk crude oil, atau campuran petroleum dan non petroleum product dalam fasa cair dan memiliki tekanan uap RVP $101,325 \mathrm{kPa}$ atau lebih kecil. Nilai density pada temperature observed dan dikoreksi pada suhu standard $15{ }^{\circ} \mathrm{C}$ atau $60{ }^{\circ} \mathrm{F}$ dengan menggunakan tabel standard ASTM D-1250.

a. Density (Kerapatan) adalah massa zat cair per satuan volume pada 15 ${ }^{\circ} \mathrm{C}$ dan $101,325 \mathrm{kPa}$ dengan satuan standar pengukuran dalam kilogram per meter kubik

b. Relative Density (berat jenis) adalah perbandingan massa sejumlah volume zat pada temperatur tertentu terhadap massa air murni dengan volume yang sama. Pada temperatur yang sama atau temperatur yang berbeda. Umumnya temperature acuan meliputi $60 / 60{ }^{\circ} \mathrm{F}, 20 / 20{ }^{\circ} \mathrm{C}, 20 / 4{ }^{\circ} \mathrm{C}$

c. API Gravity (Berat Jenis Api) adalah fungsi khusus dari Specific Gravity (Berat Jenis) pada $60 / 60{ }^{\circ} \mathrm{F}$ dinyatakan dengan $:{ }^{\circ} \mathrm{API}=\left(141,5 / \mathrm{SG} 60 / 60^{\circ} \mathrm{F}\right)-131,5$ (ASTM International \& American Petroleum Institute (API), 2017)

\section{B. Korelasi}

Ukuran yang menyatakan kedekatan antara hubungan dua variabel atau lebih disebut dengan korelasi. Pada umumnya arti korelasi digunakan untuk mengetahui seberapa dekat hubungan antar. Dalam statistik, ukuran tersebut diperoleh melalui suatu analisis korelasi. Analisis korelasi sendiri memiliki tujuan untuk mengukur seberapa derajat kedekatan relasi yang terjadi pada variabel tertentu. Analisis korelasi merupakan metode yang digunakan untuk mencari ada tidaknya hubungan antara variabel bebas dan terikat (Walpole et al., 2012).

\begin{tabular}{|c|c|c|c|c|c|c|c|c||c|c||}
\hline $\begin{array}{c}\text { Korelasitin } \\
\text { ggi }\end{array}$ & $\begin{array}{c}\text { Ting } \\
\text { gi }\end{array}$ & $\begin{array}{c}\text { Rend } \\
\text { ah }\end{array}$ & $\begin{array}{c}\text { Rend } \\
\text { ah }\end{array}$ & $\begin{array}{c}\text { Tanpakorel } \\
\text { asi }\end{array}$ & $\begin{array}{c}\text { Takadakorel } \\
\text { asi (acak) }\end{array}$ & $\begin{array}{c}\text { Tanpakorel } \\
\text { asi }\end{array}$ & $\begin{array}{c}\text { Rend } \\
\text { ah }\end{array}$ & $\begin{array}{c}\text { Rend } \\
\text { ah }\end{array}$ & $\begin{array}{c}\text { Ting } \\
\text { gi }\end{array}$ & $\begin{array}{c}\text { Korelasitin } \\
\text { ggi }\end{array}$ \\
\hline \hline-1 & $\begin{array}{c}< \\
-0.9\end{array}$ & $\begin{array}{c}> \\
-0.9\end{array}$ & $\begin{array}{c}< \\
-0.4\end{array}$ & $>-0.4$ & 0 & $<+0.4$ & $\begin{array}{c}> \\
+0.4\end{array}$ & $\begin{array}{c}< \\
+0.9\end{array}$ & $\begin{array}{c}> \\
+0.9\end{array}$ & +1 \\
\hline
\end{tabular}

Table 1 Tabel Koefisien Korelasi 


\section{Koefisien Korelasi}

Analisis korelasi ditujukan untuk mengukur hubungan antara dua peubah dengan menggunakan suatu bilangan yang disebut koefisien korelasi. $r$ sendiri dapat diperoleh dari perhitungan menggunakan rumus:

$$
\mathrm{r}=\mathrm{b} \sqrt{\frac{\mathrm{Jxx}}{\mathrm{Jyy}}}=\frac{\mathrm{Jxy}}{\sqrt{\mathrm{Jxx} \cdot \mathrm{Jyy}}}
$$

Nilai $r$ antara -1 dan + . Sebagai contoh nilai r sebesar 0,2 bukan berarti 20 persen variasi variabel terikat dapat terjelaskan melainkan yang terjelaskan adalah $(0,2) 2$ atau 4 persen (Walpole et al., 2012).

\section{Koefisien Determinasi}

Uji koefisien determinasi disebut juga uji r-square. Koefisien determinasi digunakan untuk melihat seberapa besar variabel-variabel independen secara bersama mampu memberikan penjelasan mengenai dependent variable dimana nilai $\mathrm{r} 2$ berkisar antara 0 sampai 1 . Semakin besar nilai r2, maka semakin besar variasi dependent variable yang dapat dijelaskan oleh variasi variabel - variabel independen.

Kelemahan mendasar penggunaan koefisien determinasi adalah bias terhadap jumlah variabel independen yang dimasukkan kedalam model. Setiap tambahan satu variabel independen, maka r2 pasti. Oleh karena itu banyak peneliti menganjurkan untuk menggunakan nilai adjusted r2 pada saat mengevaluasi mana model regresi terbaik. Tidak seperti $\mathrm{r} 2$, nilai adjusted $\mathrm{r} 2$ dapat naik atau turun apabila satu variabel independen ditambahkan ke dalam model.

Dalam kenyataan nilai $\mathrm{r} 2$ dapat bernilai negatif, walaupun yang dikehendaki harus bernilai positif. Jika $\mathrm{k}>1$, maka adjusted $\mathrm{r} 2=$ akan bernilai negative (Walpole et al., 2012).

\section{E. Analisis Korelasi Kendall-Tau ( $\tau$ )}

Menurut Siegel (1997) "Korelasi KendallTau $(\tau)$ adalah ukuran korelasi yang menuntut kedua variabel di ukur dalam skala ordinal sehingga obyek-obyek yang dipelajari dapat diranking dalam dua rangkaian berurut". Kendalltau ditampilkan

dengan berbagai simbol, termasuk $\tau, \mathrm{T}$, dan $\mathrm{t}$. Simbol $\tau$ digunakan untuk asosiasi yang mengacu pada populasi atau dengan kata lain simbol $\tau$ untuk menyatakan parameter populasi dan symbol $\hat{\tau}$ untuk menyatakan statistik sampelnya (Siegel, 1997).

Korelasi Kendall-tau salah satu variabelnya yang diberi peringkat (diurutkan), yaitu variabel $X$ saja atau variabel $Y$ saja dalam hal ini biasanya variabel $X$. Sedangkan variabel $Y$ itu searah (concordant) atau berlawanan arah (discordant) dengan variabel $X$ yang sudah diurutkan. Jika ada data bivariat $\left(\mathrm{X}_{\mathrm{i}}, \mathrm{Y}_{\mathrm{i}}\right), \mathrm{i}=1,2, \ldots, \mathrm{n}$ dimana $\mathrm{X}$ dan $Y$ berskala ordinal. Maka untuk setiap pasangan nilai observasi $\left(X_{i}, Y_{i}\right)$ dan $\left(X_{j}, Y_{j}\right)$ untuk $i \neq j$ dapat didefinisikan pasangan nilai sebagai berikut

Pasangan $\left(X_{i}, Y_{i}\right)$ dan $\left(X_{j}, Y_{j}\right)$ concordant, apabila $\left(X_{i}-X_{j}\right)\left(Y_{i}-Y_{j}\right)>0$.

Pasangan $\left(X_{i}, Y_{i}\right)$ dan $\left(X_{j}, Y_{j}\right)$ discordant, apabila $\left(X_{i}-X_{j}\right)\left(Y_{i}-Y_{j}\right)<0$.

Statistic uji koefisien korelasi kendall-tau adalah sebagai berikut:

$\hat{\tau}=\frac{P-Q}{0,5 n(n-1)}$

Keterangan: $\quad \hat{\tau}=$ koefisien korelasi kendall-tau $\mathrm{P}=$ banyaknya pasangan berurutan wajar $\mathrm{Q}=$ banyaknya pasangan berurutan terbalik $\mathrm{n}=$ ukuran sampel (Daniel, 1989)

Menurut Sugiyono (2009: 118) untuk menguji signifikansi koefisien korelasi kendall-tau, yaitu: $Z=\frac{\hat{\tau}}{\sqrt{\frac{2(2 N+5)}{9 N(N-1)}}}$

$\sqrt{\frac{2(2 N+5)}{9 N(N-1)}}$, kriteria uji tolak $\mathrm{H}_{0}$ jika nilai $\mathrm{p}$ dengan acuan nilai $\mathrm{Z}$ yang ditunjukan pada tabel kurang dari nilai signifikansi $\alpha$.

\section{F. Regresi}

Analisis regresidigunakanuntuk mengestimasi hubungan antara dependent variable dan variabel independen. Variabel (X) hasil pengukuran yang disebut independen digunakan untuk memprediksi atau mengestimasi besaran variabel (Y) yang disebut dependen. Syarat - syarat regresi, data haruslah bebas dari asumsi klasik statistik, yaitu:

- Normalitas

- Linieritas

- Autokorelasi

- Heteroskesdastisitas

- Multikolinearitas (regresi majemuk) 
Dalam regresi dikenal adanya dua jenis peubah, yaitu :

1. Peubah bebas (independent variable)

Adalah variabel/peubah yang nilai-nilainya tidak bergantung pada variabel lainnya.

2. Peubah terikat (dependent variable)

Adalah variabel/peubah yang nilai-nilainya bergantung pada variabel lainnya.

\section{G. Regresi Linier Sederhana}

Analisis regresi linier sederhana mengestimasi hubungan variabelnya, dimana hanya terdapat dua variabel (satu independent variable \& satu dependent variable) (Walpole et al., 2012).

Contoh dari regresi linier sederhana pada saat seorang peneliti ingin meneliti mengenai pengaruh biaya promosi terhadap volume penjualan pada perusahaan jual beli motor. Dengan ini di dapat dependent variable (y) adalah volume penjualan dan variabel independen (x) adalah biaya promosi.

Syarat dari regresi linier sederhana antara lain: tidak boleh terjadi multikolinieritas, tidak terjadi otokorelasi, terdapat hubungan linier antara variabel bebas $(\mathrm{X})$ dan variabel tergantung $(\mathrm{Y})$, data harus berdistribusi normal, data berskala interval atau rasio, terdapat hubungan dependensi, artinya satu variabel merupakan variabel tergantung yang tergantung pada variabel lainnya.

Persamaan umum :

$\mathrm{Y}^{\prime}=\mathrm{a}+\mathrm{bx} . .(3)$

$Y^{\prime}=$ dependent variable yang diprediksikan

$\mathrm{a}=$ angka konstan/harga $\mathrm{Y}$ bila $\mathrm{X}=0$

$\mathrm{b}=$ peningkatan/penurunan dependent variable yang didasarkan pada independent variable

$\mathrm{x}=$ nilai independent variable

deLangkah-langkah regresi linier sederhana antara lain: mencari harga a dan $b$, menyusun persamaan regresi, membuat garis regresi.

Cara mencari nilai a dan $\mathrm{b}$ :

$$
\begin{aligned}
& \mathrm{a}=\frac{\sum_{\mathrm{i}=1}^{\mathrm{n}} \mathrm{y}_{\mathrm{i}}-\mathrm{b} \sum_{\mathrm{i}=1}^{\mathrm{n}} \mathrm{x}_{\mathrm{i}}}{\mathrm{n}} \ldots(4) \\
& \mathrm{b}=\frac{\mathrm{n} \sum_{\mathrm{i}=1}^{\mathrm{n}} \mathrm{x}_{\mathrm{i} \mathrm{y}_{1}}-\left[\sum_{\mathrm{i}=1}^{\mathrm{n}} \mathrm{x}_{\mathrm{i}}\right]\left[\sum_{\mathrm{i}=1}^{\mathrm{n}} \mathrm{y}_{1}\right]}{\mathrm{n} \sum_{\mathrm{i}=1}^{\mathrm{n}} \mathrm{x}_{\mathrm{i}}^{2}-\left[\sum_{\mathrm{i}=1}^{\mathrm{n}} \mathrm{x}_{\mathrm{i}}\right]^{2}} . .
\end{aligned}
$$

\section{Uji Autokorelasi}

Uji autokorelasi bertujuan untuk menguji apakah terdapat korelasi residual pada periode $\mathrm{t}$ dengan periode $\mathrm{t}-1$ (periode sebelumnya). Hal inilah yang disebut autokorelasi antara dua data. Ada beberapa cara untuk mengetahui autokorelasi, yang paling popular dengan uji Durbin, Walson. Suatu model regresi yang baik harus tidak terjadi autokorelasi (Walpole et al., 2012).

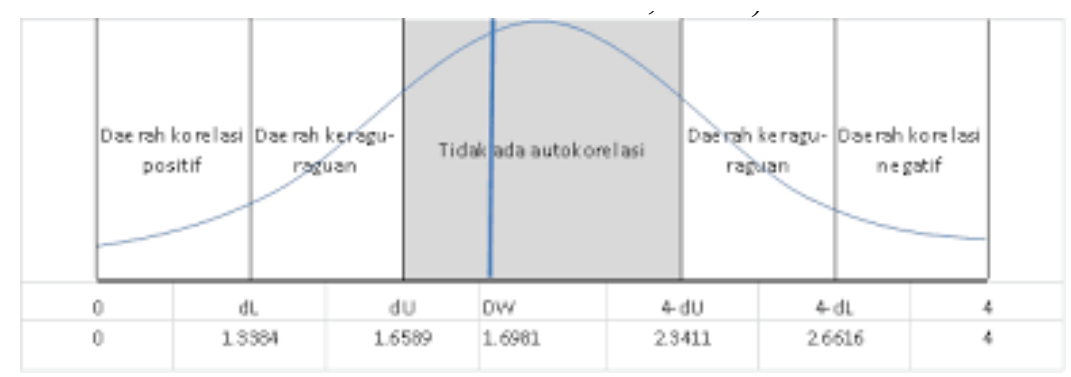

Gambar 1 Contoh Output Uji Autokorelsai

\section{Uji Heteroskedastisitas}

Uji Heteroskesdastisitas bertujuan untuk menguji apakah dalam model regresi terjadi ketidaksamaan variansi residual dari pengamatan satu ke pengamatan lain. Jika variansi tetap (tidak ada perbedaan) maka disebut homoskesdastisitas. Suatu model regresi yang baik haruslah memenuhi asumsi heteroskedastisitas (Walpole et al., 2012).

Pengujian heteroskedastisitas dengan metode grafik lazim dipergunakan meskipun menimbulkan bias, karena pengamatan antara satu pengamat dengan pengamat lain bisa menimbulkan perbedaan persepsi. Oleh karena itu, penggunaan uji statistik diharapkan menghilangkan unsur bias tersebut. Salah satu uji statistik yang lazim dipergunakan adalah uji Glejser (di samping uji yang lain, misalnya uji Park, atau uji White). Uji Glejser dilakukan dengan meregresikan variabel-variabel bebas terhadap nilai absolut residualnya (Gujarati, 2004). 


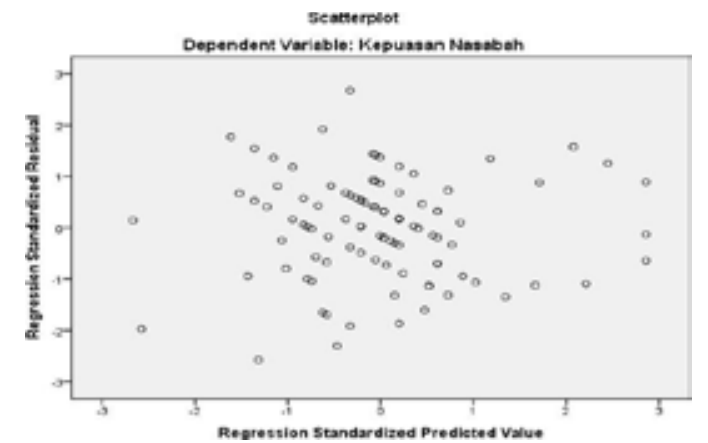

Gambar 2 Contoh Output Uji Heteroskesdestisitas

Metode Theil untuk Regresi Lineir Sederhana Non-Parametrik

Asumsi-asumsi Metode Theil

Data yang tersedia merupakan sebuah sampel acak yang terdiri atas $\mathrm{n}$ pasangan pengamatan $\left(\mathrm{X}_{\mathrm{i}}, \mathrm{Y}_{\mathrm{i}}\right)$.

Untuk masing-masing nilai $\mathrm{X}_{\mathrm{i}}$ terdapat sebuah subpopulasi nilai-nilai Y.

$\mathrm{Y}_{\mathrm{i}}$ adalah nilai yang teramati dari $\mathrm{Y}$ yang acak dan kontinu untuk nilai $\mathrm{X}_{\mathrm{i}}$.

Semua nilai $\mathrm{X}_{\mathrm{i}}$ berbeda dan ditetapkan $\mathrm{X}_{1}<\mathrm{X}_{2}<\cdots<\mathrm{X}_{\mathrm{n}}$.

\section{Estimasi Model}

Model regresi linear dengan pemenuhan terhadap asumsi kenormalan dapat digunakan regresi parametrik untuk mengetahui bentuk hubungan antar peubah regresi. Penyimpangan terhadap asumsi-asumsi itu sering terjadi di dalam praktik, dan terkadang peubah acak yang diamati tidak dapat dianggap menyebar normal.

Teknik-teknik dari segi statistik parametrik yang digunakan berhubungan dengan pendugaan parameter serta pengujian hipotesis yang berhubungan dengan parameter-parameter. Asumsi-asumsi yang digunakan pada umumnya menspesifikasikan bentuk sebarannya. Salah satu alternatif lain yang dapat digunakan adalah dengan regresi nonparametrik, karena dalam regresi nonparametrik tidak diperlukan pemenuhan asumsi kenormalan.
Misalkan ada $\mathrm{n}$ pasangan pengamatan ( $\left.\mathrm{X}_{1}, \mathrm{Y}_{1}\right),\left(\mathrm{X}_{2}, \mathrm{Y}_{2}\right), \ldots,\left(\mathrm{X}_{\mathrm{n}}, \mathrm{Y}_{\mathrm{n}}\right)$, persamaan regresi linear sederhana adalah:

$$
\mathrm{Y}_{\mathrm{i}}=\beta_{0}+\beta_{1} \mathrm{X}_{\mathrm{i}}+\varepsilon_{\mathrm{i}}
$$

dengan $\beta_{0}$ adalah intercept (titik potong) terhadap sumbu Y.

$\beta_{1}$ adalah slope (kemiringan) dari garis regresi

$\mathrm{X}_{\mathrm{i}}$ adalah peubah bebas

$\mathrm{Y}_{\mathrm{i}}$ adalah nilai teramati dari peubah $\mathrm{Y}$ (Montgomery et al., 1990)

Theil (1950) dalam Sprent (1991) mengusulkan koefisien kemiringan (slope) garis regresi sebagai median kemiringan dari seluruh pasangan garis dari titik-titik dengan nilai $X$ yang berbeda, selanjutnya disebut dengan metode Theil. Misalkan sebuah sampel yang terdiri atas $\mathrm{n}$ pasangan hasil pengamatan $\left(\mathrm{X}_{1}, \mathrm{Y}_{1}\right),\left(\mathrm{X}_{2}, \mathrm{Y}_{2}\right), \ldots,\left(\mathrm{X}_{\mathrm{n}}, \mathrm{Y}_{\mathrm{n}}\right)$ dengan variabel-variabel $\mathrm{X}$ dan $\mathrm{Y}$ kontinu, dimana pasangan $\left(\mathrm{X}_{\mathrm{i}}, \mathrm{Y}_{\mathrm{i}}\right)$ merupakan hasilhasil pengukuran terhadap unit asosiasi yang sama (ke-i). Untuk satu pasangan $\left(X_{i}, Y_{i}\right)$ dan $\left(X_{j}, Y_{j}\right)$ koefisien kemiringannya adalah (Sprent, 1991):

$$
b_{i j}=\frac{Y_{j}-Y_{i}}{X_{j}-X_{i}} \text {, untuk } i<j \text { dan } X_{i} \neq X_{j}
$$

\section{H. Pengujian Koefisien Slope ( $\beta$ _1)}

Daniel (1989) menjelaskan bahwa pengujian koefisien kemiringan dengan menggunakan metode Theil disusun berdasarkan statistik ${ }^{\tau}$ Kendall dan digunakan 
untuk mengetahui bentuk hubungan peubahpeubah regresi (Daniel, 1989).

Asumsi-asumsi yang melandasi pengujian pada koefisien kemiringan adalah:

(1) Persamaan regresinya adalah $Y_{i}=\beta_{0}+\beta_{1} X_{i}+\varepsilon_{i}, \mathrm{i}=1,2, \ldots, \mathrm{n}$ dengan $X_{i}$ peubah bebas, $\beta_{0}$ dan $\beta_{1}$ adalah parameter-parameter yang tidak diketahui.

(2) Untuk masing-masing nilai Xi terdapat sebuah subpopulasi nilai-nilai Y.

(3) $Y_{i}$ adalah nilai yang teramati dari $\mathrm{Y}$ yang acak dan kontinu untuk nilai $X_{i}$.

(4) Semua nilai $X_{i}$ berbeda dan ditetapkan $X_{1}<X_{2}<\cdots<X_{n}$

(5) Nilai-nilai $\varepsilon_{i}$ saling bebas dan berasal dari populasi yang sama.

Hipotesis yang digunakan adalah hipotesis dua sisi yaitu sebagai berikut.

$$
H_{0}: \beta=\beta_{0}
$$$$
H_{1}: \beta \neq \beta_{0}
$$

Seperti yang telah dijelaskan, prosedur yang diuraikan disusun berlandaskan statistic $\hat{\tau}$ Kendall, sehingga statistik ujinya adalah:

$$
\hat{\tau}=\frac{{ }_{P-Q}}{0,5 n(n-1)}
$$

Dengan $\hat{\tau}=$ statistik uji $\tau$ Kendall

$\mathrm{n}=$ banyak pasangan

$\mathrm{P}=$ banyaknya pasangan berurutan wajar

$\mathrm{Q}=$ banyaknya pasangan berurutan terbalik

Kriteria uji:

$$
\begin{aligned}
& |\hat{\tau}|>\tau^{*}\left(n, \frac{\alpha}{2}\right) \text {, tolak } H_{0} \\
& |\hat{\tau}| \leq \tau^{*}\left(n, \frac{\alpha}{2}\right) \text {, jangan tolak } H_{0}
\end{aligned}
$$

"Pengujian koefisien kemiringan ini dengan membuat statistik tataan dan memperbandingkan semua hasil pengamatan menurut nilai-nilai X” (Daniel, 1989).

\section{Pengujian Koefisien Regresi secara Overall}

Hipotesis yang digunakan untuk menguji keberartian model regresi adalah:

$H_{0}: \beta_{i}=0$ : tidak terdapat hubungan antara variabel $\mathrm{X}$ dan variabel $\mathrm{Y}$.

$H_{1}: \beta_{i} \neq 0$ : terdapat hubungan antara variabel $\mathrm{X}$ dan variabel $\mathrm{Y}$.

Statistic ujinya:

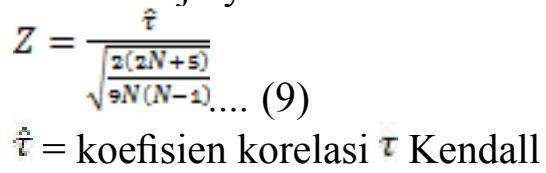

Kriteria Uji: Tolak $H_{0}$ jika $p_{z} \leq \frac{\alpha}{2}$, terima dalam hal lain.

\section{J. Interval Kepercayaan Koefisien Regresi Slope}

Metode pembentukan intervalkepercayaan terhadap koefisien kemiringan ini dilandaskan pada prosedur pengujian hipotesis Theil untuk $\beta_{1}$, sedangkan asumsi-asumsi yang mendasari prosedur pengujian hipotesis ini juga berlaku pada pembentukan interval kepercayaan $(1-\alpha)$ bagi $\beta_{1}$.

Lebih lanjut Daniel (1989) menjelaskan bahwa konstanta untuk interval kepercayaan adalah :

$$
k=\frac{c_{2}^{n}-S_{\left(n-\frac{\alpha}{2}\right)^{-2}}}{2} \ldots(10)
$$

Dengan $\mathrm{k}=$ konstanta untuk interval kepercayaan.

$C_{2}^{n}=$ banyaknya nilai $b_{i j}$ yang mungkin dari $n$ pasangan pengamatan.

$S_{\left(n, \frac{\alpha}{2}\right)}=$ titik kritis $\tau$ Kendall untuk $\mathrm{n}$ pasangan pengamatan pada taraf $\alpha$.

Berdasarkan nilai konstanta tersebut akan diperoleh $\overline{\beta_{L}}$ sebagai batas bawah interval kepercayaan untuk $\beta_{1}$ dan $\bar{\beta}_{U}$ sebagai batas atas interval kepercayaan untuk $\beta_{1} . \beta_{L}$ adalah nilai $b_{i j}$ ke-k yang dihitung dari nilai yang paling kecil dalam statistik tataan bagi nilai $b_{i j} . \beta_{U}$ adalah nilai $b_{i j}$ ke-k yang dihitung mundur dari nilai yang paling besar dalam 
statistik tataan tersebut.

Menurut Daniel (1989) interval kepercayaan untuk $\beta_{1}$ dengan suatu koefisien kepercayaan $(1-\alpha)$ adalah:

$$
C\left(\widetilde{\beta_{L}}<\beta_{1}<\widetilde{\beta_{U}}\right)=1-\alpha
$$

dengan $\mathrm{C}$ adalah kependekan dari confidence (kepercayaan) dan menunjukkan bahwa ekspresi ini lebih merupakan suatu pernyataan kepercayaan daripada suatu pernyataan probabilitas.

\section{METODE PENELITIAN}

Data yang dikumpulkan merupakan data laporan hasil density obs pada produk crude oil di unit kilang PPSDM Migas Cepu selama bulan Desember 2020. Pelaporan hasil pengolahan kilang PPSDM Migas dilakukan setiap hari, dengan tiap harinya terdiri dari 3 shift kerja dan tiap shift kerja dilakukan pengecekan sebanyak 2 kali. Berikut table 2 merupakan rekap laporan hasil density observed (biasa ditulis dengan density obs) pada produk crude oil:

Table 2 Data Hasil Density Observed Produk Crude Oil

\begin{tabular}{|c|c|c|c|c|c|c|c|c|c|}
\hline Tanggal & Shift & Jam & Density/ Temp & Temperature & \multirow{6}{*}{$\begin{array}{c}5 \\
\text { Desember } \\
2020\end{array}$} & \multirow{2}{*}{1} & 00:00 & 826 & 30 \\
\hline \multirow{7}{*}{$\begin{array}{c}1 \\
\text { Desember } \\
2020\end{array}$} & \multirow[b]{2}{*}{1} & $00: 00$ & 826 & $\frac{(\mathrm{C})(\mathrm{X})}{31}$ & & & 04:00 & 826 & 30 \\
\hline & & $04 \cdot 00$ & $\begin{array}{l}020 \\
826\end{array}$ & $\begin{array}{l}51 \\
30\end{array}$ & & 2 & 08:00 & 826 & 33 \\
\hline & \multirow{3}{*}{2} & & & & & 2 & $12: 00$ & 826 & 32 \\
\hline & & $\frac{08: 00}{12 \cdot 00}$ & $8 \angle 0$ & 32 & & \multirow{2}{*}{3} & $16: 00$ & 825 & 33 \\
\hline & & $\frac{12.00}{16.00}$ & $8 \angle 5$ & 34 & & & $20: 00$ & 825 & 32 \\
\hline & \multirow[t]{2}{*}{3} & $16: 00$ & 826 & 33 & \multirow{7}{*}{$\begin{array}{c}6 \\
\text { Desember } \\
2020\end{array}$} & \multirow{2}{*}{1} & 00:00 & 826 & 30 \\
\hline & & $20: 00$ & 826 & 32 & & & 04:00 & 826 & 30 \\
\hline \multirow{6}{*}{$\begin{array}{c}2 \\
\text { Desember } \\
2020\end{array}$} & \multirow{2}{*}{1} & 00:00 & 826 & 30 & & & 08:00 & 826 & 32 \\
\hline & & 04:00 & 826 & 30 & & 2 & $12 \cdot 00$ & 826 & 33 \\
\hline & \multirow{2}{*}{2} & 08:00 & 826 & 32 & & \multirow{3}{*}{3} & & & 53 \\
\hline & & $12: 00$ & 826 & 31 & & & 16:00 & 826 & 33 \\
\hline & \multirow{2}{*}{3} & $16: 00$ & 825 & 34 & & & 20:00 & 827 & 31 \\
\hline & & $20: 00$ & 826 & 33 & \multirow{6}{*}{$\begin{array}{c}7 \\
\text { Desember } \\
2020\end{array}$} & \multirow{2}{*}{1} & 00:00 & 827 & 31 \\
\hline \multirow{6}{*}{$\begin{array}{c}3 \\
\text { Desember } \\
2020\end{array}$} & \multirow[b]{2}{*}{1} & 00:00 & 826 & 30 & & & 04:00 & 827 & 30 \\
\hline & & 04:00 & 826 & 30 & & 2 & 08:00 & 826 & 30 \\
\hline & \multirow[b]{2}{*}{2} & 08:00 & 826 & 31 & & 2 & $12: 00$ & 826 & 32 \\
\hline & & $12: 00$ & 825 & 34 & & 3 & $16: 00$ & 827 & 32 \\
\hline & \multirow[b]{2}{*}{3} & $16 \cdot 00$ & 825 & 33 & & 3 & $20: 00$ & 827 & 31 \\
\hline & & $\frac{10.00}{20.00}$ & 025 & & \multirow{6}{*}{$\begin{array}{c}8 \\
\text { Desember } \\
2020\end{array}$} & \multirow{2}{*}{1} & 00:00 & 827 & 31 \\
\hline \multirow{6}{*}{$\begin{array}{c}4 \\
\text { Desember } \\
2020\end{array}$} & \multirow{3}{*}{1} & $\frac{20: 00}{00 \cdot 00}$ & 825 & 32 & & & 04:00 & 827 & 30 \\
\hline & & $\frac{00.00}{04.00}$ & 825 & & & & 08:00 & 826 & 31 \\
\hline & & $\begin{array}{l}04.00 \\
08 \cdot 00\end{array}$ & 826 & 33 & & 2 & $12: 00$ & 826 & 32 \\
\hline & \multirow[t]{2}{*}{2} & $12 \cdot 00$ & 824 & 35 & & \multirow{2}{*}{3} & $16: 00$ & 826 & 31 \\
\hline & & $\frac{12: 00}{16 \cdot 00}$ & 824 & 35 & & & 20:00 & 826 & 31 \\
\hline & 3 & $20: 00$ & $\begin{array}{l}825 \\
825\end{array}$ & $\begin{array}{l}33 \\
32\end{array}$ & & & & & \\
\hline
\end{tabular}


Artikel

\begin{tabular}{|c|c|c|c|c|c|c|c|c|c|}
\hline \multirow{6}{*}{$\begin{array}{c}9 \\
\text { Desember } \\
2020\end{array}$} & \multirow{2}{*}{1} & 00:00 & 826 & 31 & \multirow{6}{*}{$\begin{array}{c}16 \\
\text { Desember } \\
2020\end{array}$} & \multirow{2}{*}{1} & 00:00 & 823 & 31 \\
\hline & & 04:00 & 826 & 31 & & & 04:00 & 823 & 31 \\
\hline & \multirow{2}{*}{2} & 08:00 & 827 & 30 & & \multirow{2}{*}{2} & 08:00 & 822 & 31 \\
\hline & & 12:00 & 826 & 31 & & & $12: 00$ & 821 & 33 \\
\hline & \multirow{2}{*}{3} & $16: 00$ & 826 & 31 & & \multirow{2}{*}{3} & $16: 00$ & 823 & 32 \\
\hline & & $20: 00$ & 826 & 31 & & & $20: 00$ & 823 & 31 \\
\hline \multirow{6}{*}{$\begin{array}{c}10 \\
\text { Desember } \\
2020\end{array}$} & \multirow{2}{*}{1} & $00: 00$ & 826 & 30 & \multirow{6}{*}{$\begin{array}{c}17 \\
\text { Desember } \\
2020\end{array}$} & \multirow{2}{*}{1} & 00:00 & 822 & 30 \\
\hline & & 04:00 & 826 & 30 & & & 04:00 & 822 & 30 \\
\hline & \multirow{2}{*}{2} & 08:00 & 828 & 31 & & \multirow{2}{*}{2} & 08:00 & 822 & 31 \\
\hline & & 12:00 & 826 & 32 & & & $12: 00$ & 822 & 32 \\
\hline & \multirow{2}{*}{3} & $16: 00$ & 827 & 30 & & \multirow{2}{*}{3} & $16: 00$ & 822 & 31 \\
\hline & & $20: 00$ & 826 & 31 & & & 20:00 & 822 & 31 \\
\hline \multirow{6}{*}{$\begin{array}{c}11 \\
\text { Desember } \\
2020\end{array}$} & \multirow{2}{*}{1} & 00:00 & 827 & 30 & \multirow{6}{*}{$\begin{array}{c}18 \\
\text { Desember } \\
2020\end{array}$} & \multirow{2}{*}{1} & 00:00 & 822 & 30 \\
\hline & & 04:00 & 827 & 30 & & & 04:00 & 822 & 30 \\
\hline & \multirow{2}{*}{2} & 08:00 & 827 & 31 & & \multirow{2}{*}{2} & 08:00 & 822 & 31 \\
\hline & & 12:00 & 826 & 32 & & & 12:00 & 822 & 32 \\
\hline & \multirow{2}{*}{3} & $16: 00$ & 826 & 31 & & 3 & $16: 00$ & 822 & 30 \\
\hline & & $20: 00$ & 826 & 31 & & 3 & $20: 00$ & 822 & 32 \\
\hline & 1 & 00:00 & 827 & 30 & & 1 & 00:00 & 822 & 30 \\
\hline & 1 & 04:00 & 826 & 32 & & 1 & 04:00 & 822 & 30 \\
\hline & & 08:00 & 828 & 31 & $\begin{array}{c}19 \\
\text { Desember }\end{array}$ & 2 & 08:00 & 822 & 31 \\
\hline $\begin{array}{l}\text { Desember } \\
2020\end{array}$ & 2 & 12:00 & 826 & 32 & 2020 & & 12:00 & 822 & 32 \\
\hline & & $16: 00$ & 826 & 31 & & 3 & 16:00 & 822 & 32 \\
\hline & 3 & $20: 00$ & 826 & 31 & & 3 & $20: 00$ & 822 & 31 \\
\hline & 1 & 00:00 & 826 & 31 & & 1 & 00:00 & 822 & 30 \\
\hline & 1 & 04:00 & 826 & 32 & & 1 & 04:00 & 822 & 30 \\
\hline $\begin{array}{c}13 \\
\text { Desember }\end{array}$ & 2 & 08:00 & 827 & 31 & $\begin{array}{c}20 \\
\text { Desember }\end{array}$ & 2 & 08:00 & - & - \\
\hline $\begin{array}{l}\text { Desember } \\
2020\end{array}$ & 2 & $12: 00$ & 826 & 32 & 2020 & 2 & 12:00 & - & - \\
\hline & 3 & $16: 00$ & 823 & 32 & & 3 & 16:00 & 824 & 30 \\
\hline & 3 & $20: 00$ & 824 & 31 & & & 20:00 & - & - \\
\hline & & 00:00 & 824 & 32 & & 1 & 00:00 & - & - \\
\hline & 1 & 04:00 & 823 & 32 & & 1 & 04:00 & - & - \\
\hline 14 & & 08:00 & 823 & 31 & $\begin{array}{c}21 \\
\text { Desember }\end{array}$ & 2 & 08:00 & 830 & 29 \\
\hline $\begin{array}{c}\text { Desember } \\
2020\end{array}$ & 2 & $12: 00$ & 821 & 32 & 2020 & 2 & 12:00 & 828 & 31 \\
\hline & 3 & $16: 00$ & 823 & 33 & & 3 & 16:00 & - & - \\
\hline & 3 & $20: 00$ & 823 & 32 & & & 20:00 & - & - \\
\hline & 1 & 00:00 & 823 & 32 & & 1 & 00:00 & - & - \\
\hline & 1 & 04:00 & 824 & 32 & & 1 & 04:00 & - & - \\
\hline $\begin{array}{c}15 \\
\text { December }\end{array}$ & & 08:00 & 822 & 31 & $\begin{array}{c}22 \\
\text { Desember }\end{array}$ & 2 & 08:00 & 825 & 33 \\
\hline $\begin{array}{l}\text { Desember } \\
2020\end{array}$ & 2 & $12: 00$ & 822 & 32 & $\begin{array}{l}\text { Desember } \\
2020\end{array}$ & 2 & 12:00 & 824 & 35 \\
\hline & 3 & $16: 00$ & 823 & 31 & & 3 & 16:00 & 824 & 34 \\
\hline & 3 & $20: 00$ & 823 & 31 & & 5 & 20:00 & 825 & 33 \\
\hline
\end{tabular}




\begin{tabular}{|c|c|c|c|c|}
\hline \multirow{6}{*}{$\begin{array}{c}23 \\
\text { Desember } \\
2020\end{array}$} & \multirow{2}{*}{1} & 00:00 & 827 & 30 \\
\hline & & 04:00 & 827 & 30 \\
\hline & \multirow{2}{*}{2} & 08:00 & 826 & 32 \\
\hline & & $12: 00$ & 825 & 35 \\
\hline & \multirow{2}{*}{3} & $16: 00$ & 825 & 34 \\
\hline & & $20: 00$ & 826 & 33 \\
\hline \multirow{6}{*}{$\begin{array}{c}24 \\
\text { Desember } \\
2020\end{array}$} & \multirow{2}{*}{1} & 00:00 & 827 & 30 \\
\hline & & 04:00 & 827 & 30 \\
\hline & \multirow{2}{*}{2} & 08:00 & 826 & 32 \\
\hline & & $12: 00$ & 825 & 35 \\
\hline & \multirow{2}{*}{3} & $16: 00$ & 825 & 34 \\
\hline & & $20: 00$ & 826 & 32 \\
\hline \multirow{6}{*}{$\begin{array}{c}25 \\
\text { Desember } \\
2020\end{array}$} & \multirow{2}{*}{1} & 00:00 & 827 & 30 \\
\hline & & 04:00 & 827 & 30 \\
\hline & \multirow{2}{*}{2} & 08:00 & 826 & 32 \\
\hline & & $12: 00$ & 825 & 35 \\
\hline & \multirow{2}{*}{3} & $16: 00$ & 826 & 33 \\
\hline & & $20: 00$ & 826 & 32 \\
\hline \multirow{6}{*}{$\begin{array}{c}26 \\
\text { Desember } \\
2020\end{array}$} & \multirow{2}{*}{1} & 00:00 & 827 & 30 \\
\hline & & 04:00 & 827 & 30 \\
\hline & \multirow{2}{*}{2} & 08:00 & 826 & 32 \\
\hline & & $12: 00$ & 826 & 33 \\
\hline & \multirow{2}{*}{3} & $16: 00$ & 826 & 32 \\
\hline & & $20: 00$ & 826 & 31 \\
\hline \multirow{6}{*}{$\begin{array}{c}27 \\
\text { Desember } \\
2020\end{array}$} & \multirow{2}{*}{1} & 00:00 & 826 & 31 \\
\hline & & 04:00 & 826 & 31 \\
\hline & \multirow{2}{*}{2} & 08:00 & 826 & 31 \\
\hline & & $12: 00$ & 826 & 32 \\
\hline & \multirow{2}{*}{3} & $16: 00$ & 825 & 34 \\
\hline & & $20: 00$ & 826 & 32 \\
\hline \multirow{6}{*}{$\begin{array}{c}28 \\
\text { Desember } \\
2020\end{array}$} & \multirow{2}{*}{1} & 00:00 & 826 & 31 \\
\hline & & 04:00 & 826 & 31 \\
\hline & \multirow{2}{*}{2} & 08:00 & 826 & 31 \\
\hline & & $12: 00$ & 826 & 32 \\
\hline & \multirow{2}{*}{3} & $16: 00$ & 825 & 32 \\
\hline & & 20:00 & 826 & 31 \\
\hline
\end{tabular}




\section{HASIL DAN PEMBAHASAN \\ Uji Hipotesis \\ Uji Hipotesis 1}

1. H0 $: \rho=0$ (Tidak ada hubungan linier antara variable $\mathrm{X}$ dan variable $\mathrm{Y}$ )

2. H1 $\rho \neq 0$ (Ada hubungan linier antara variable $\mathrm{X}$ dan variable $\mathrm{Y}$ )

3. $\alpha=0,05$

4. Daerah kritis dengan df $=176, \mathrm{t}>$ 1,97353 dan $\mathrm{t}<-1,97353$, didapatkan dari tabel L.4 (Walpole) bersifat dwisisi

5. Perhitungan

$t=\frac{r \sqrt{n-2}}{1-r^{2}}=\frac{-0,153 \sqrt{175}}{1-(-0,153)^{2}}=-2,042$

6. Keputusan:

Tolak H0 karena t-hitung berada pada daerah kritis dimana $-2,042<-1,97353$

7. Kesimpulan: Ada hubungan linier antara variable $\mathrm{X}$ dan variable $\mathrm{Y}$

\section{Uji Hipotesis Kedua}

1. Ho : $\rho=0,9$ (Terdapat hubungan antara variable $\mathrm{x}$ dan y yang sangat erat)

2. $\mathrm{H}_{1}=\rho<0,9$ (Tidak terdapat hubungan antara variable $\mathrm{x}$ dan $\mathrm{y}$ yang sangat erat)

3. $\alpha=0,05$

4. Daerah kritis $\mathrm{z}>-1,64$ didapatkan dari

$$
z=\frac{\sqrt{174}}{2} \ln \left[\frac{(1-0,153)(1-0,9)}{(1+0,153)(1+0,9)}\right]
$$$$
z=-21,448
$$

6. Keputusan : Jangan Tolak Ho karena z-hitung berada diluar daerah kritis dimana Zhitung $<$ Ztabel yaitu $-21,448$ $<-1,64$

7. Kesimpulan : Terdapat hubungan antara variable $x$ dan y yang sangat erat

\section{Uji Asumsi Klasik}

\section{Uji Linieritas}

Hipotesis

1. $\mathrm{H}_{0}$ : model regresi bersifat linear

2. $\mathrm{H}_{1}$ : model regresi tidak bersifat linear

3. $\alpha: 0,05$

4. Daerah kritis : $p<0,05$

5. Perhitungan :

Berikut merupakan hasil output menggunakan software SPSS:

\begin{tabular}{|c|c|c|c|c|c|c|c|}
\hline & & & $\begin{array}{l}\text { Sum of } \\
\text { Squares }\end{array}$ & df & $\begin{array}{l}\text { Mean } \\
\text { Square }\end{array}$ & $\mathrm{F}$ & Sig. \\
\hline \multirow{5}{*}{$\begin{array}{l}\text { Density* } \\
\text { Temperature }\end{array}$} & \multirow{3}{*}{$\begin{array}{l}\text { Between } \\
\text { Groups }\end{array}$} & (Combined) & 36,531 & 6 & 6,089 & 2,092 & ,057 \\
\hline & & Linearity & 12,367 & 1 & 12,367 & 4,250 &, 041 \\
\hline & & $\begin{array}{l}\text { Deviation } \\
\text { from Linearity }\end{array}$ & 24,164 & 5 & 4,833 & 1,661 & , 147 \\
\hline & \multicolumn{2}{|c|}{ Within Groups } & 494,734 & 170 & 2,910 & & \\
\hline & \multicolumn{2}{|l|}{ Total } & 531,266 & 176 & & & \\
\hline
\end{tabular}

Table 3 Output Uji Linieritas ANOVA Table

6. Keputusan: Jangan tolak H0 untuk nilai deviation of linearity karena 0,147 $>0,05$

7. Kesimpulan: Data model bersifat regresi linier 


\section{Uji Normalitas}

Hipotesis

1. $\mathrm{H}_{0}$ : data residual berdistribusi normal

2. $\mathrm{H}_{1}$ : data residual tidak berdistribusi normal

3. $\alpha: 0,05$

4. Daerah kritis : $\operatorname{sig}<0,05$

5. Perhitungan:

Berikut merupakan hasil output menggunakan software SPSS:
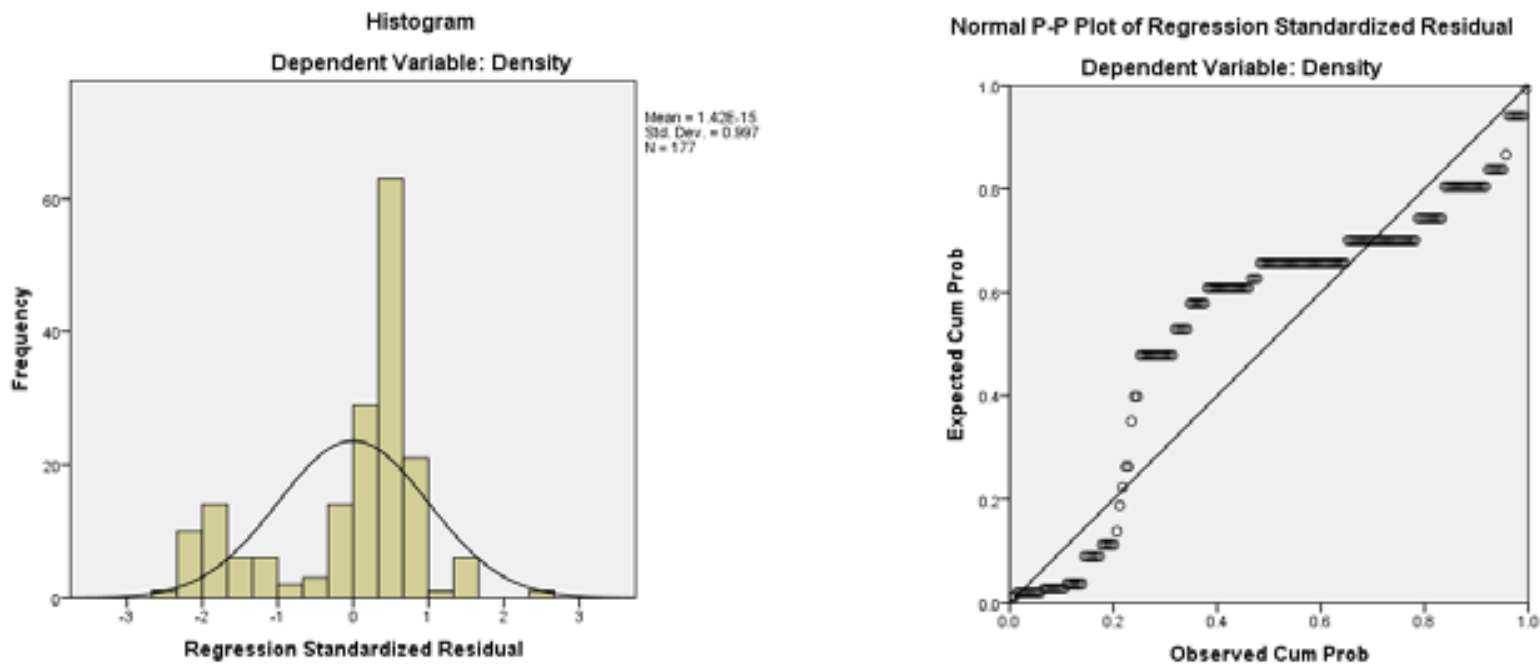

Gambar 5 Grafik Histogram dan Grafik Normal P-P Plot Uji Normalitas

Table 3 Output Uji Normalitas One-Sample Kolmogorov-Smirnov Test

\begin{tabular}{|ll|r|}
\hline & & \multicolumn{2}{|c|}{$\begin{array}{c}\text { Unstandardized } \\
\text { Residual }\end{array}$} \\
\hline $\mathrm{N}$ & Mean & 177 \\
Normal Parameters ${ }^{\mathrm{a}, \mathrm{b}}$ & Std. Deviation &, 0000000 \\
& Absolute & 1,71705711 \\
Most Extreme Differences & Positive &, 234 \\
& Negative &, 117 \\
& &,- 234 \\
Test Statistic & &, 234 \\
Asymp. Sig. (2-tailed) & & $.000^{\mathrm{c}}$ \\
\hline
\end{tabular}

a. Test distribution is Normal.

b. Calculated from data.

c. Lilliefors Significance Correction.

6. Keputusan: Karena nilai sig 0,000 $<0,05$ maka tolak H0

7. Kesimpulan: Data residual tidak berdistribusi normal 


\section{Uji Autokorelasi}

Hipotesis

1. $\mathrm{H}_{0}$ : Residual tidak terjadi autokorelasi

2. $\mathrm{H}_{1}$ : Residual terjadi autokorelasi

3. $\alpha: 0,05$

4. Daerah kritis : $\mathrm{k}=1, \mathrm{n}=177$

Dw $>2,2573$ dan $\mathrm{Dw}<1,7427$

5. Perhitungan :

Berikut merupakan hasil output menggunakan software SPSS:

\section{Table 4 Output Uji Autokorelasi}

Model Summary ${ }^{b}$

\begin{tabular}{|c|c|c|c|c|c|c|c|c|c|c|}
\hline \multirow[b]{2}{*}{$\begin{array}{l}\text { Mod- } \\
\text { el }\end{array}$} & \multirow[b]{2}{*}{$\mathrm{R}$} & \multirow[b]{2}{*}{$\begin{array}{c}\mathrm{R} \\
\text { Square }\end{array}$} & \multirow[b]{2}{*}{$\begin{array}{c}\text { Adjusted } \\
\text { R } \\
\text { Square }\end{array}$} & \multirow[b]{2}{*}{$\begin{array}{l}\text { Std. } \\
\text { Error of } \\
\text { the sti- } \\
\text { mate }\end{array}$} & \multicolumn{5}{|c|}{ Change Statistics } & \multirow[b]{2}{*}{$\begin{array}{l}\text { Dur } \\
\text { bin- } \\
\text { Wat } \\
\text { son }\end{array}$} \\
\hline & & & & & $\begin{array}{c}\mathrm{R} \\
\text { Square } \\
\text { Change }\end{array}$ & $\begin{array}{c}\text { F } \\
\text { Chang } \\
\text { e }\end{array}$ & df1 & df2 & $\begin{array}{l}\text { Sig. F } \\
\text { Change }\end{array}$ & \\
\hline 1 & $.153^{\mathrm{a}}$ & 023 &, 018 & 1,722 &, 023 & 4,171 & 1 & 175 & ,043 & ,261 \\
\hline
\end{tabular}

\section{a. Predictors: (Constant), Temperature}

b. Dependent Variable: Density

6. Keputusan: Tolak H0 karena nilai 0,261 $<1,7427$

7. Kesimpulan: Residual terjadi autokorelasi 
Uji Heteroskedastisitas

Hipotesis

1. $\mathrm{H}_{0}$ : data regresi bersifat homoskedastisitas

2. $\mathrm{H}_{1}$ : data regresi bersifat heteroskedastisitas

3. $\alpha: 0,05$

4. Daerah kritis : $\operatorname{sig}<0,05$

5. Perhitungan :

Berikut merupakan hasil output menggunakan software SPSS:

Table 5 Output Uji Heteroskedastisitas dengan Uji Glejser Coefficients $^{a}$

\begin{tabular}{|cc|c|c|c|c|c|c|c|}
\hline \multirow{2}{*}{ Model } & \multicolumn{2}{|c|}{$\begin{array}{c}\text { Unstandardized } \\
\text { Coefficients }\end{array}$} & $\begin{array}{c}\text { Standardized } \\
\text { Coefficients }\end{array}$ & \multirow{2}{*}{$\mathrm{t}$} & \multirow{2}{*}{ Sig. } & \multicolumn{2}{|c|}{$\begin{array}{c}\text { 95,0\% Confidence } \\
\text { Interval for B }\end{array}$} \\
\cline { 2 - 4 } & $\mathrm{B}$ & $\begin{array}{c}\text { Std. } \\
\text { Error }\end{array}$ & Beta & & & $\begin{array}{c}\text { Lower } \\
\text { Bound }\end{array}$ & $\begin{array}{c}\text { Upper } \\
\text { Bound }\end{array}$ \\
\hline & (Constant) & 9,625 & 1,980 & & 4,862 &, 000 & 5,718 & 13,532 \\
1 & Temperature &,- 263 &, 063 &,- 302 & $-4,188$ &, 000 &,- 387 &,- 139 \\
\hline
\end{tabular}

a. Dependent Variable: Abs_RES

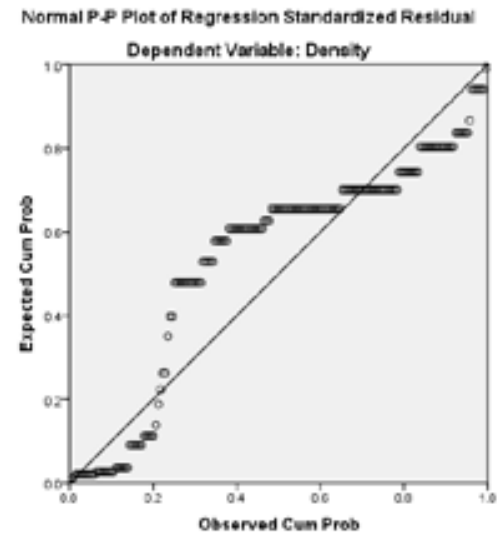

\section{Grafik 6 Normal P-P Plot Uji Heteroskedastisitas}

6. Kesimpulan: Tolak Ho karena nilai sig $0,00<0,05$

7. Keputusan: data regresi bersifat heteroskedastisitas 
Berdasarkan dari hasil uji asumsi klasik yang telah dilakukan di atas diperoleh hasil bahwa data regresi tidak lolos pada beberapa uji, yaitu pada uji Normalitas, uji Autokorelasi, dan uji Heteroskedastisitas. Karena beberapa syarat regresi pada uji asumsi klasik tidak terpenuhi, maka data regresi tidak dapat dilakukan pengolahan dengan pendekatan analisis regresi linier parametrik sehingga selanjutnya akan dilakukan analisis regresi linier non-parametrik.

\section{Analisis Regresi Linier Non Parametrik Model Regresi}

Metode Estimasi yang digunakan dalam penelitian ini adalah regresi sederhana metode Theil, dengan spesifikasi model sebagai berikut.

$$
Y_{1}=\beta_{0}+\beta_{1} X_{1}+\varepsilon_{1}
$$

Untuk mendapatkan Model Regresi nonparametrik metode Theil dengan rumusan:

$$
b_{i j}=\frac{Y_{j}-Y_{i}}{X_{j}-X_{i}} \text {, untuk } i<j \text { dan } X_{i} \neq X_{j}
$$

Data tentang pengaruh temperature terhadap density crude oil kemudian disusun terurut sehingga peringkat-peringkat $\mathrm{X}$ memiliki urutan wajar dari $\mathrm{X}$ yang terkecil sampai $\mathrm{X}$ yang terbesar. (Lampiran 1 )

Untuk memperoleh nilai $b_{i j}$ karena data berobservasi angka sama dan sesuai asumsi metode Theil nilai $X_{i}$ berbeda maka data yang nilai X-nya sama nilai Y-nya dibuat rata-rata, sehingga di dapat data baru sebagai berikut.

Table 4. 7 Data Baru Pengaruh

\begin{tabular}{|c|c|c|}
\hline No & $\mathbf{X}$ & $Y$ \\
\hline 1 & 29 & 830 \\
\hline 2 & 30 & 825,425 \\
\hline 3 & 31 & 825,404 \\
\hline 4 & 32 & 824,843 \\
\hline 5 & 33 & 825,188 \\
\hline 6 & 34 & 824,857 \\
\hline 7 & 35 & 824,6 \\
\hline
\end{tabular}
Temperature terhadap Density Crude Oil
(29;830) diperbandingkan dengan pasangan pengamatan $(30 ; 825,425)$ diperoleh nilai $b_{i j}$ sebagai berikut

$$
\begin{aligned}
& b_{1,2}=\frac{825,425-830}{30-29}=-4,575 \\
& b_{1,2} \text { merupakan nilai } b_{i j} \text { yang pertama }
\end{aligned}
$$
yang diperoleh dari pasangan pengamatan pertama dengan pasangan pengamatan kedua. Keseluruhan nilai ${ }^{b_{i j}}$ yang lain hasilnya dapat dilihat pada lampiran 2.

Penduga bagi $\beta_{1}$ dinotasikan dengan $\overline{\beta_{1}}$ dinyatakan sebagai median dari nilai-nilai $b_{i j}$ sehingga:

$$
\bar{\beta}_{1}=\operatorname{median}\left(b_{i j}\right)=-0,257
$$

Sedangkan penduga bagi $\beta_{0}$ adalah $\widetilde{\beta_{0}}$ dimana:

$$
\begin{gathered}
\widetilde{\beta_{0}}=\text { median }\left(Y_{i}\right)-\widetilde{\beta_{1}} \text { median }\left(X_{i}\right) \\
\widetilde{\beta_{0}}=825,425-(-0,257)(30)=833,139
\end{gathered}
$$

Sehingga didapat model: $\widehat{Y_{i}}=833,139-0,257 X_{i}$

Akan tetapi model regresi di atas belum dapat dikatakan sebagai model regresi terbaik, Untuk itu selain harus diidentifikasi terlebih dahulu, perlu dilihat apakah model tersebut koefisiennya berarti atau tidak dengan uji hipotesis.

$$
\begin{aligned}
& \text { Pengujian Koefisien Slope }\left(\boldsymbol{\beta}_{\mathbf{1}}\right) \\
& \text { Hipotesis: } \\
& H_{0}: \beta_{1}=0 \\
& H_{1}: \beta_{1} \neq 0
\end{aligned}
$$

Statistik uji:

$$
\hat{\tau}=\frac{P-Q}{0,5 n(n-1)}
$$

Untuk memperoleh nilai $P_{i}$ dan $Q_{i}$, diperoleh dengan cara membandingkan setiap nilai pengamatan $\mathrm{Y}$ satu demi satu dengan setiap nilai $\mathrm{Y}$ yang ada disebelah bawahnya. Nilai $P_{i}$ adalah jumlah banyaknya nilai di bawah baris $\mathrm{Y}$ yang dihitung jumlahnya, tetapi angkanya yang lebih besar dari angka pada baris $Y$ tersebut. Nilai $Q_{i}$ adalah jumlah nilai di bawah baris $\mathrm{Y}$ yang dihitung jumlahnya, 
tetapi angkanya yang lebih kecil dari angka pada baris $Y$ tersebut.

Misalkan $P_{4}$ pada baris ke-empat jumlahnya 2, hal ini terdiri atas nilai $\mathrm{Y}$ yang di atas nilai 824,843 sebagai berikut: 825,188 ; 824,857 .

Misalkan $Q_{1}$ pada baris pertama jumlahnya 6 , hal ini terdiri atas nilai $Y$ yang di

bawah nilai 830 sebagai berikut: 825,425 ; 825,$404 ; 824,843 ; 825,188 ; 824,857 ; 824,600$.

Hasil lainnya dapat dilihat pada table 8 sebagai berikut:

Table 8 Nilai $P$ dan $Q$ pada Pengaruh Temperature terhadap Density Crude Oil

\begin{tabular}{|c|c|c|c|c|c|}
\hline No & $\mathrm{X}$ & $\mathrm{Y}$ & $\mathrm{Pi}$ & $\mathrm{Oi}$ & \\
\hline 1 & 29 & 830,000 & 0 & 6 & $p_{z}=0,5-P(Z=-2,55)=0,5-$ \\
\hline 2 & 30 & 825,425 & 0 & 5 & $0,4946=0,0054$ \\
\hline 3 & 31 & 825,404 & 0 & 4 & Dengan $\alpha=0,05$, maka $\frac{\alpha}{2}=0,025$ \\
\hline 4 & 32 & 824,843 & 2 & 1 & Kesimpulan: \\
\hline 5 & 33 & 825,188 & 0 & 2 & Ternyata $p_{z}=0,0054 \leq \frac{\alpha}{2}=0,025$ \\
\hline 6 & 34 & 824,857 & 0 & 1 & tolak $H_{0}$ artinya model ini bisa digunakan untuk \\
\hline 7 & 35 & 824,600 & 0 & 0 & menyatakan hubungan antara temperature dan \\
\hline Jumlah & 224 & 5780,316 & 2 & 19 & density crude oil. \\
\hline
\end{tabular}
$P=\sum P_{i}=0+0+0+2+\cdots+0=2$

$$
\begin{aligned}
& Q=\sum Q_{i}=6+5+4+1+\cdots+0=19 \\
& \mathrm{n}=7 \\
& \hat{\tau}=\frac{2-19}{0,5 \times 7(7-1)}=-0,81
\end{aligned}
$$

Kriteria Uji:

$|\hat{\imath}|>\tau^{*}\left(n, \frac{\alpha}{2}\right)$, tolak $H_{0}$

$|\hat{\tau}| \leq \tau^{*}\left(n, \frac{\alpha}{2}\right)$, jangan tolak $H_{0}$

Dengan $\alpha=0,05$, maka $\frac{\alpha}{2}=0,025$

Kesimpulan:

Dengan $\mathrm{n}=7$ dan taraf nyata 0,025 maka $\tau^{*}$ tabel $=0,714$, karena $|\hat{\tau}|=0,81>\tau^{*}$ tabel $=0,714 \quad \mathrm{~m} \quad$ a $\quad \mathrm{k} \quad \mathrm{a}$ jangan tolak $H_{0}$, artinya mengindikasikan bahwa koefisien slope temperature sangat berpengaruh terhadap density crude oil.

\section{Pengujian Koefisien Regresi secara}

\section{Overall}

$H_{0}: \beta_{i}=0$ : tidak terdapat hubungan antara variabel $\mathrm{X}$ dan variabel $\mathrm{Y}$.

$H_{1}: \beta_{i} \neq 0$ : terdapat hubungan antara variabel $\mathrm{X}$ dan variabel $\mathrm{Y}$.

Statistik ujinya:

$$
Z=\frac{\hat{\imath}}{\sqrt{\frac{2(2 N+5)}{9 N(N-1)}}}=\frac{-0,81}{\sqrt{\frac{2(2 \times 7+5)}{9 \times 7(7-1)}}}=-2,55
$$

Kriteria uji:

Tolak $H_{0}$ jika $p_{z} \leq \frac{\alpha}{2}$, jangan tolak $H_{0}$ jika $>\frac{\alpha}{2}$

$$
4946=0,0054
$$

Dengan $\alpha=0,05$, maka $\frac{\alpha}{2}=0,025$

Kesimpulan: di table 9 sebagai berikut:

Table 9 Uji Korelasi Kendall's Tau Correlations

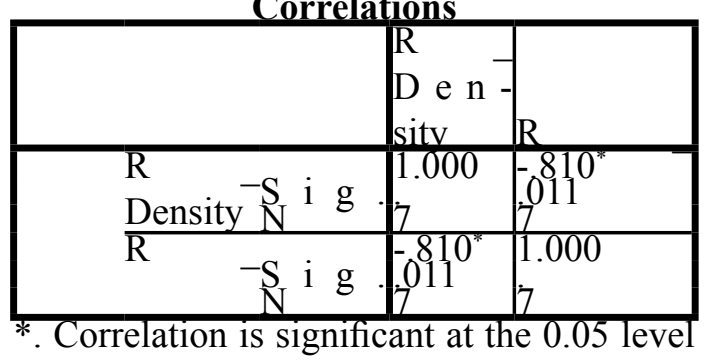

(2-tailed).

Berdasar tabel Correlation didapat nilai korelasi Kendall-Tau sebesar $-0,810$, berarti ada korelasi antara temperature dan density crude oil sebesar 0,810 . Tingkat signifikansi $0,011<0,05$ maka $H_{0}$ ditolak artinya terdapat hubungan antara temperature dan density crude oil. 
Interval Kepercayaan Koefisien Regresi Slope

Konstanta untuk interval kepercayaan adalah:

$$
k=\frac{C_{2}^{n}-S_{\left(n, \frac{\alpha}{2}\right)}-2}{2}
$$

Dari data temperature dan density crude oil dengan $\mathrm{n}=7$ maka diperoleh $C_{2}^{7}=21$ pasang dan nilai $S_{(7,0,025)}=15$, sehingga interval kepercayaannya adalah sebagai berikut.

$$
k=\frac{21-15-2}{2}=2
$$

Dengan demikian, $\widehat{\beta_{L}}$ adalah nilai $\mathrm{ke}-2$ dari nilai $b_{i j}$ yang paling kecil, dan $\widehat{\beta_{U}}$ adalah nilai ke-2 dari nilai ${ }^{b_{i j}}$ yang terbesar.

$$
\widehat{\beta_{L}}=-2,298
$$

$\widehat{\beta_{U}}=0,007$

Karena $1-2(0,025)=0,95$, maka interval kepercayaan untuk $\beta_{1}$ dapat dituliskan sebagai $C\left(-2,298<\beta_{1}<0,007\right)=0,95$ Artinya 95\% bahwa koefisien regresi slope akan berada dalam interval $-2,298<\beta_{1}<0,007$.

\section{Analisis Hasil}

\section{Uji Asumsi Klasik}

\section{- Uji Linieritas}

Berdasarkan hasil output nilai signifikan dari deviation from linearity adalah sebesar 0,147 . Nilai tersebut menandakan bahwa data tersebut bersifat linear karena berada di luar nilai kritis dengan $\alpha=0,05$. Berdasarkan perhitungan tersebut, dapat disimpulkan bahwa nilai linearitas yang dimiliki oleh variabel independen dan dependen memiliki hubungan yang linier secara signifikan.

\section{- Uji Normalitas}

Uji normalitas merupakan suatu uji untuk mengetahui apakah terdapat persebaran data berdistribusi normal atau tidak. Kegunaan uji ini adala agar data yang diuji tidak berada di bawah duga atau diluar duga sehingga menyebabkan uji ANOVA tidak valid.
Berdasarkan hasil output nilai sig residual $0,00<0,05$. Hal tersebut menandakan bahwa data residual tidak berdistribusi normal dan tidak lolos uji normalitas.

\section{- Uji Autokorelasi}

Uji autokorelasi bertujuan untuk menguji apakah pada model regresi terdapat korelasi antara residual pada periode ke-t dengan residual pada periode sebelumnya ( $\mathrm{t}-1)$. Pada perhitungan ini digunakan uji Durbin Watson, dimana untuk mendapatkan regresi yang baik maka suatu model harus tidak terjadi autokorelasi. Pada percobaan ini dihasilkan nilai uji Durbin Watson sebesar 0,261 dengan daerah kritis $\mathrm{dw}>2,2573 \mathrm{dan} \mathrm{dw}<1,7427$. Nilai tersebut berada pada daerah kritis dimana $0,261<1,7427$, yang mana hal ini menunjukkan bahwa model regresi terjadi autokorelasi positif.

\section{- Uji Heteroskedastisitas}

Uji heteroskedastisitas bertujuan untuk menguji apakah dalam model regresi terjadi ketidaksamaan variansi residual dari satu pengamatan ke pengamatan lainnya. Jika variansi tetap, maka homoskesdastisitas. Berdasarkan hasil output scatterplot, titik-titik data berpola dan tidak menyebar, berdasarkan uji glejser nilai signifikansi yang didapat 0,000 $<0,05$ sehingga dapat disimpulkan bahwa model regresi bersifat heteroskesdastisitas atau dapat dikatakan terjadi ketidaksamaan variansi dari residu satu pengamatan dengan pengamatan lainnya

Dari pengujian asumsi klasik yang telah dilakukan, dapat disimpulkan bahwa data yang digunakan dalam penelitian ini tidak memenuhi syarat pada uji asumsi tersebut. Uji asumsi yang tidak terpenuhi dapat disebabkan karena terdapat variable independent lain selain temperature yang memiliki pengaruh signifikan terhadap variable dependent yaitu density crude oil.

Dengan tidak terpenuhinya salah satu atau lebih asumsi maka Langkah selanjutnya 
ialah menggunakan statistic non parametrik yang dapat digunakan untuk mencocokkan garis regresi linear dengan data sampel yang teramati adalah metode iterative BrownMood, metode Weigted median dan metode Theil.

Dari ketiga metode di atas metode Theil adalah yang paling baik, karena penelitian bersama yang dilakukan Sprent dan Smeeton (1991) berpendapat bahwa metode Theil hampir seefisien metode kuadrat terkecil jika asumsi kenormalan error terpenuhi. Metode Theil adalah metode nonparametrik yang digunakan untuk mengestimasi parameterparameter dan menganalisis garis-garis regresi linear dengan data sampel yang teramati dikarenakan error tidak menyebar.

\section{Regresi Linier Non-Parametrik}

Dari pengujian hipotesis yang telah dilakukan, dapat diketahui bahwa metode Theil merupakan metode nonparametrik yang dapat digunakan untuk mencocokan garis regresi linear. Metode Theil efektif dan efisien untuk data yang semua nilai $X_{i}$ berbeda dan jika ada nilai $X_{i}$ yang sama maka dicari rataratanya pada nilai $Y_{i}$ yang nilai $X_{i}$-nya sama tersebut.

Untuk mendapatkan model regresi nonparametrik dengan metode Theil langkah-langkahnya adalah mencari nilai $b_{i j}$ , menentukan median $b_{i j}$, median $X_{i}$, median $Y_{i}$ dan Untuk pengujian koefisien slope $\left(\beta_{1}\right)$ dan pengujian koefisien regresi secara overall dicari dengan menggunakan rumus statistik Tau Kendall. Pengujian koefisien regresi secara overall dengan menggunakan program SPSS dapat dilakukan dengan uji koefisien korelasi kendall-tau. Kriteria ujinya adalah tolak $H_{0}$ jika nilai Sig. (2-tailed) kurang dari $\alpha$. Untuk mencari interval kepercayaan koefisien regresi slope dengan mencari konstanta interval kepercayaan koefisien regresi slope dan menentukan nilai $\widehat{\beta_{L}}$ dan $\widetilde{\beta_{U}}$.
Berdasarkan contoh kasus analisis regresi linear sederhana diperoleh persamaan regresi $\widehat{Y}_{\imath}=833,139-0,257 X_{i} . \quad$ Dalam pengujian koefisien regresi slope didapat $\hat{\tau}=-0,81$, dengan $\mathrm{n}=7$ dan taraf nyata 0,025 maka $\tau^{*}$ tabel $=0,714, \quad$ karena $|\hat{\tau}|=0,81>\tau^{*}$ tabel $=0,714$, maka tolak $H_{0}$, yang artinya mengindikasikan bahwa koefisien kemiringan berarti temperature sangat berpengaruh terhadap densitas crude oil. Pada pengujian koefisien regresi secara overall didapat $Z_{\text {hitung }}=-2,553$, ternyata $p_{z}=0,0054 \leq \frac{\alpha}{2}=0,025$ maka tolak $H_{0}$ artinya model ini bisa digunakan untuk menyatakan hubungan antara temperature $(\mathrm{X})$ dan density crude oil (Y). Dengan program SPSS dalam pengujian koefisien regresi secara overall didapat nilai korelasi KendallTau sebesar $-0,810$, berarti ada korelasi antara temperature dan density crude oil sebesar 0,810. Tingkat signifikansi $0,011<0,05$ maka $H_{0}$ ditolak artinya terdapat hubungan antara temperature dan density crude oil. Koefisien regresi slope antara temperature dan density crude oil berada dalam interval $-2,298<\beta_{1}<0,007$

Analisis korelasi digunakan untuk mengetahui apakah variable dependent dengan independent memiliki hubungan. Untuk mengetahui hubungan tersebut, digunakan suatu bilangan yang disebut dengan koefisien korelasi $(\rho)$

\section{- Tingkat kekuatan (keeratan) hubungan antar variable}

Dalam menentukan tingkat kekuatan hubungan antar variable, dapat berpedoman pada nilai koefisien korelasi. Berdasarkan output pada pengolahan data, diperoleh angka koefisien korelasi sebesar -0,810*. Artinya, tingkat kekuatan hubungan (korelasi) antara temperature dan density crude oil adalah sebesar 0,810 atau memiliki korelasi yang sangat kuat. Tanda bintang $\left(^{*}\right)$ artinya korelasi 
bernilai signifikan pada angka signifikansi sebesar 0,05 .

\section{- Arah (jenis) hubungan antar variable}

Arah korelasi dilihat pada angka koefisien korelasi sebagaimana tingkat kekuatan korelasi. Besarnya nilai koefisien korelasi terletak antara +1 sampai dengan -1. Jika koefisien korelasi bernilai positif, maka hubungan kedua variable dikatakan searah. Jika koefisien korelasi bernilai negative, maka hubungan kedua variable tidak searah.

Angka koefisien korelasi pada hasil di atas bernilai negative, yaitu $-0,810$, sehingga hubungan kedua variable tersebut bersifat berlawanan arah, dengan demikian dapat diartikan bahwa semakin meningkat temperature maka density crude oil akan menurun.

\section{- Signifikansi korelasi}

Kekuatan dan arah korelasi akan mempunyai arti jika hubungan antar varaibel bernilai signifikan. Dikatakan ada hubungan signifikan, jika nilai Sig. (2-tailed) hasil perhitungan lebih kecil dari 0,05. Sementara jika nilai Sig. (2-tailed) lebih besar dari 0,05 maka hubungan antar variable dapat dikatakan tidak signifikan atau tidak berarti.

Berdasarkan output di atas, diketahui nilai signifikansi atau Sig. (2-tailed) sebesar 0,011. Karena nilai Sig (2-tailed) 0,011<0,05 maka artinya ada hubungan yang signifikan (berarti) antara variabel temperature dengan density crude oil.

\section{KESIMPULAN}

1. Model regresi liner sederhana non parametrik dengan metode Theil pada data pengaruh temperature terhadap density crude oil PPSDM Migas Cepu bulan Desember 2020 adalah: $\quad \widehat{Y}_{\imath}=833,139-0,257 X_{i} \quad$ dengan $\widehat{Y}_{t}$ adalah nilai dugaan dependent variable $Y_{i}$ (density of crude oil) dan $X_{i}$ adalah independent variable (temperature crude oil).
2. Hasil pengujian menunjukkan bahwa pada taraf nyata 0,05 temperature berpengaruh terhadap density crude oil. Korelasi antara temperature dengan density crude oil memiliki korelasi yang sangat kuat dengan nilai korelasi Kendall-Tau sebesar $-0,810$ dan hubungan kedua variable tersebut bersifat berlawanan arah, yang dapat diartikan bahwa semakin meningkat temperature maka density crude oil akan menurun.

3. Selangkepercayaan 0,95 koefisienslope berada pada selang $-2,298<\beta_{1}<0,007$, artinya dengan keyakinan $95 \%$ disimpulkan bahwa density crude oil akan berkurang hingga 2,298 atau bertambah hingga $0,007 \mathrm{~kg} /$ $\mathrm{m}^{3}$ untuk setiap pertambahan $1{ }^{\circ} \mathrm{C}$ temperature.

\section{DAFTAR PUSTAKA}

A, N. W., Nohe, D. A., \& Goejantoro, R. (2016). Penerapan Statistika Nonparametrik dengan Metode Brown-Mood pada Regresi Linier Berganda. EKSPONENSIAL, 1-8.

ASTM International, \& American Petroleum Institute (API). (2017). Standard Test Method for Density, Relative Density, or API Gravity of Crude Petroleum and Liquid Petroleum Products by Hydrometer Method. $i$ (Reapproved), 1-8. https://doi.org/10.1520/ D1298-12BR17.2

Daniel, W. W. (1989). Statistika Non Parametrik Terapan. Gramedia Pustaka Utama.

Gujarati, D. (2004). Basic Econometrics (Ekonometrika Dasar). Gramedia Pustaka Utama.

Humas, P. M. (2021a). Sejarah PPSDM Migas. PPSDM MIGAS. https://ppsdmmigas. esdm.go.id/id/Landing/sejarah

Humas, P.M. (2021b). StrukturOrganisasi. PPSDM MIGAS. https://ppsdmmigas.esdm. go.id/id/Landing/struktur_organisasi

Humas, P. M. (2021) $)$. Tentang Kami. PPSDM MIGAS. https://ppsdmmigas.esdm. go.id/id/Landing/tentang_kami 
Khoiri, I. A. (2018). EVALUASI untuk Ilmu-ilmu Sosial. Gramedia Pustaka EFISIENSI FURNACE 01 PADA UNIT Utama.

KILANG. Universitas Pembangunan Nasional

"Veteran" Yogyakarta.

Montgomery, D. C., Soejoeti, Z., \& Sunabar. (1990). Pengantar Pengendalian Kualitas Statistik (Subanar (ed.)). Gadjah Mada University Press.

Siegel, S. (1997). Statistik Nonparametrik

\section{Lampiran 1}

Penyusunan Data Terurut pada Temperature dan Density Crude Oil

\begin{tabular}{|c|c|c|}
\hline No & $\begin{array}{c}\text { Density/ } \text { Temp }^{\circ} \mathrm{C} \\
\text { Obs } \\
\text { (Y) } \\
\end{array}$ & $\begin{array}{c}\text { Temperature }\left({ }^{\circ} \mathrm{C}\right) \\
(\mathrm{X})\end{array}$ \\
\hline 1 & 830 & 29 \\
\hline 2 & 826 & 30 \\
\hline 3 & 826 & 30 \\
\hline 4 & 826 & 30 \\
\hline 5 & 826 & 30 \\
\hline 6 & 826 & 30 \\
\hline 7 & 826 & 30 \\
\hline 8 & 826 & 30 \\
\hline 9 & 826 & 30 \\
\hline 10 & 826 & 30 \\
\hline 11 & 826 & 30 \\
\hline 12 & 827 & 30 \\
\hline 13 & 826 & 30 \\
\hline 14 & 827 & 30 \\
\hline 15 & 827 & 30 \\
\hline 16 & 826 & 30 \\
\hline 17 & 826 & 30 \\
\hline 18 & 827 & 30 \\
\hline 19 & 827 & 30 \\
\hline 20 & 827 & 30 \\
\hline 21 & 827 & 30 \\
\hline 22 & 822 & 30 \\
\hline 23 & 822 & 30 \\
\hline 24 & 822 & 30 \\
\hline 25 & 822 & 30 \\
\hline 26 & 822 & 30 \\
\hline 27 & 822 & 30 \\
\hline 28 & 822 & 30 \\
\hline
\end{tabular}

\section{perature dan Density Crude Oil}

Sprent, P. (1991). Metode Statistika Nonparametrik Terapan. UI-Press.

Walpole, R. E., Myers, R. H., Myers, S. L., \& Ye, K. (2012). Probability \& Statistics for Engineers \& Scientists (D. Lynch (ed.); 9th ed.). Prentice Hall. 


\begin{tabular}{|c|c|c|c|c|c|}
\hline 58 & 826 & 31 & 100 & 826 & 32 \\
\hline 59 & 827 & 31 & 101 & 826 & 32 \\
\hline 60 & 826 & 31 & 102 & 825 & 32 \\
\hline 61 & 826 & 31 & 103 & 825 & 32 \\
\hline 62 & 828 & 31 & 104 & 825 & 32 \\
\hline 63 & 826 & 31 & 105 & 826 & 32 \\
\hline 64 & 826 & 31 & 106 & 825 & 32 \\
\hline 65 & 826 & 31 & 107 & 826 & 32 \\
\hline 66 & 827 & 31 & 108 & 826 & 32 \\
\hline 67 & 824 & 31 & 109 & 827 & 32 \\
\hline 68 & 823 & 31 & 110 & 826 & 32 \\
\hline 69 & 822 & 31 & 111 & 826 & 32 \\
\hline 70 & 823 & 31 & 112 & 826 & 32 \\
\hline 71 & 823 & 31 & 113 & 826 & $\begin{array}{l}32 \\
32\end{array}$ \\
\hline 72 & 823 & 31 & $\begin{array}{l}114 \\
115\end{array}$ & $\begin{array}{l}826 \\
826\end{array}$ & 32 \\
\hline 73 & 823 & 31 & & & \\
\hline 74 & 822 & 31 & 116 & 826 & 32 \\
\hline 75 & 823 & 31 & 117 & 823 & 32 \\
\hline 76 & 822 & 31 & 118 & 824 & 32 \\
\hline 77 & 822 & 31 & 119 & 823 & 32 \\
\hline 78 & 822 & 31 & 120 & 821 & 32 \\
\hline 79 & 822 & 31 & 121 & 823 & 32 \\
\hline 80 & 822 & 31 & 122 & 823 & 32 \\
\hline 81 & 822 & 31 & 123 & 824 & 32 \\
\hline 82 & 828 & 31 & 124 & 822 & 32 \\
\hline 83 & 826 & 31 & 125 & 823 & 32 \\
\hline 84 & 826 & 31 & 126 & 822 & 32 \\
\hline 85 & 826 & 31 & 127 & 822 & 32 \\
\hline 86 & 826 & 31 & 128 & 822 & 32 \\
\hline 87 & 826 & 31 & 129 & 822 & 32 \\
\hline 88 & 826 & 31 & 130 & 822 & 32 \\
\hline 89 & 826 & 31 & 131 & 826 & 32 \\
\hline 90 & 826 & 31 & 132 & 826 & 32 \\
\hline 91 & 828 & 31 & 133 & 826 & 32 \\
\hline 92 & 828 & 31 & 134 & 826 & 32 \\
\hline 93 & 828 & 31 & 135 & 826 & 32 \\
\hline 94 & 826 & 31 & 136 & 826 & 32 \\
\hline 95 & 826 & 31 & 137 & 826 & 32 \\
\hline 96 & 826 & 31 & 138 & 826 & 32 \\
\hline 97 & 826 & 31 & & & \\
\hline 98 & 826 & 31 & & & \\
\hline 99 & 826 & 32 & & & \\
\hline
\end{tabular}




\begin{tabular}{|c|c|c|}
\hline 139 & 826 & 32 \\
\hline 140 & 826 & 32 \\
\hline 141 & 825 & 32 \\
\hline 142 & 825 & 32 \\
\hline 143 & 825 & 32 \\
\hline 144 & 825 & 32 \\
\hline 145 & 825 & 32 \\
\hline 146 & 825 & 32 \\
\hline 147 & 826 & 32 \\
\hline 148 & 825 & 32 \\
\hline 149 & 825 & 32 \\
\hline 150 & 826 & 33 \\
\hline 151 & 826 & 33 \\
\hline 152 & 825 & 33 \\
\hline 153 & 826 & 33 \\
\hline 154 & 825 & 33 \\
\hline 155 & 826 & 33 \\
\hline 156 & 825 & 33 \\
\hline 157 & 826 & 33 \\
\hline 158 & 826 & 33 \\
\hline 159 & 823 & 33 \\
\hline 160 & 821 & 33 \\
\hline 161 & 825 & 33 \\
\hline 162 & 825 & 33 \\
\hline 163 & 826 & 33 \\
\hline 164 & 826 & 33 \\
\hline 165 & 826 & 33 \\
\hline 166 & 825 & 34 \\
\hline 167 & 825 & 34 \\
\hline 168 & 825 & 34 \\
\hline 169 & 824 & 34 \\
\hline 170 & 825 & 34 \\
\hline 171 & 825 & 34 \\
\hline 172 & 825 & 34 \\
\hline 173 & 824 & 35 \\
\hline 174 & 824 & 35 \\
\hline 175 & 825 & 35 \\
\hline 176 & 825 & 35 \\
\hline 177 & 825 & 35 \\
\hline
\end{tabular}

\section{Lampiran 2 \\ Table Nilai ${ }^{b_{\text {if }}}$ Data Pengaruh Temperature Terhadap Density Crude Oil}

\begin{tabular}{|c|c|c|c|c|c|}
\hline No & $\boldsymbol{X}_{\boldsymbol{i}}$ & $\boldsymbol{Y}_{\boldsymbol{i}}$ & $\boldsymbol{X}_{\boldsymbol{j}}$ & $\boldsymbol{Y}_{\boldsymbol{j}}$ & $\boldsymbol{b}_{\boldsymbol{i f}}$ \\
\hline 1 & 29 & 830,000 & 30 & 825,425 & $-4,575$ \\
2 & 29 & 830,000 & 31 & 825,404 & $-2,298$ \\
3 & 29 & 830,000 & 32 & 824,843 & $-1,719$ \\
4 & 29 & 830,000 & 33 & 825,188 & $-1,203$ \\
5 & 29 & 830,000 & 34 & 824,857 & $-1,029$ \\
6 & 29 & 830,000 & 35 & 824,600 & $-0,900$ \\
7 & 30 & 825,425 & 31 & 825,404 & $-0,021$ \\
8 & 30 & 825,425 & 32 & 824,843 & $-0,291$ \\
9 & 30 & 825,425 & 33 & 825,188 & $-0,079$ \\
10 & 30 & 825,425 & 34 & 824,857 & $-0,142$ \\
11 & 30 & 825,425 & 35 & 824,600 & $-0,165$ \\
12 & 31 & 825,404 & 32 & 824,843 & $-0,560$ \\
13 & 31 & 825,404 & 33 & 825,188 & $-0,108$ \\
14 & 31 & 825,404 & 34 & 824,857 & $-0,182$ \\
15 & 31 & 825,404 & 35 & 824,600 & $-0,201$ \\
16 & 32 & 824,843 & 33 & 825,188 & 0,344 \\
17 & 32 & 824,843 & 34 & 824,857 & 0,007 \\
18 & 32 & 824,843 & 35 & 824,600 & $-0,081$ \\
19 & 33 & 825,188 & 34 & 824,857 & $-0,330$ \\
20 & 33 & 825,188 & 35 & 824,600 & $-0,294$ \\
21 & 34 & 824,857 & 35 & 824,600 & $-0,257$ \\
\hline
\end{tabular}

